\title{
Tropospheric carbon monoxide over the Pacific during HIPPO: two-way coupled simulation of GEOS-Chem and its multiple nested models
}

\author{
Y.-Y. Yan, J.-T. Lin, Y. Kuang, D. Yang, and L. Zhang \\ Laboratory for Climate and Ocean-Atmosphere Studies, Department of Atmospheric and Oceanic Sciences, \\ School of Physics, Peking University, Beijing 100871, China
}

Correspondence to: J.-T. Lin (linjt@pku.edu.cn)

Received: 17 June 2014 - Published in Atmos. Chem. Phys. Discuss.: 21 July 2014

Revised: 27 October 2014 - Accepted: 31 October 2014 - Published: 2 December 2014

\begin{abstract}
Global chemical transport models (CTMs) are used extensively to study air pollution and transport at a global scale. These models are limited by coarse horizontal resolutions that do not allow for a detailed representation of small-scale nonlinear processes over the pollutant source regions. Here we couple the global GEOS-Chem CTM and its three high-resolution nested models to simulate the tropospheric carbon monoxide (CO) over the Pacific Ocean during five High-performance Instrumented Airborne Platform for Environmental Research (HIAPER) Pole-to-Pole Observations (HIPPO) campaigns between 2009 and 2011. We develop a two-way coupler, the PeKing University CouPLer (PKUCPL), allowing for the exchange and interaction of chemical constituents between the global model (at $2.5^{\circ}$ long. $\times 2^{\circ}$ lat.) and the three nested models (at $0.667^{\circ}$ long. $\times 0.5^{\circ}$ lat.) covering Asia, North America, and Europe. The coupler obtains nested model results to modify the global model simulation within the respective nested domains, and simultaneously acquires global model results to provide lateral boundary conditions (LBCs) for the nested models.

Compared to the global model alone, the two-way coupled simulation results in enhanced $\mathrm{CO}$ concentrations in the nested domains. Sensitivity tests suggest the enhancement to be a result of improved representation of the spatial distributions of $\mathrm{CO}$, nitrogen oxides, and non-methane volatile organic compounds, the meteorological dependence of natural emissions, and other resolution-dependent processes. The relatively long lifetime of $\mathrm{CO}$ allows for the enhancement to be accumulated and carried across the globe. We found that the two-way coupled simulation increased the global tropo-
\end{abstract}

spheric mean CO concentrations in 2009 by $10.4 \%$, with a greater enhancement at $13.3 \%$ in the Northern Hemisphere. Coincidently, the global tropospheric mean hydroxyl radical $(\mathrm{OH})$ was reduced by $4.2 \%$, resulting in a $4.2 \%$ enhancement in the methyl chloroform lifetime (MCF; via reaction with tropospheric $\mathrm{OH}$ ). The resulting $\mathrm{CO}$ and $\mathrm{OH}$ contents and MCF lifetime are closer to observation-based estimates.

Both the global and the two-way coupled models capture the general spatiotemporal patterns of HIPPO CO over the Pacific. The two-way coupled simulation is much closer to HIPPO CO, with a mean bias of $1.1 \mathrm{ppb}(1.4 \%)$ below $9 \mathrm{~km}$ compared to the bias at $-7.2 \mathrm{ppb}(-9.2 \%)$ for the global model alone. The improvement is most apparent over the North Pacific. Our test simulations show that the global model alone could resemble the two-way coupled simulation (especially below $4 \mathrm{~km}$ ) by increasing its global $\mathrm{CO}$ emissions by $15 \%$ for HIPPO- 1 and HIPPO-3, by $25 \%$ for HIPPO-2 and HIPPO-4, and by $35 \%$ for HIPPO-5. This has important implications for using the global model alone to constrain CO emissions. Thus, the two-way coupled simulation is a significantly improved model tool for studying the global impacts of air pollutants from major anthropogenic source regions.

\section{Introduction}

Global air pollution and transport are of interest worldwide, concerning the impacts on atmospheric chemistry, environment, and climate (Akimoto, 2003; Fiore et al., 2009; HTAP, 


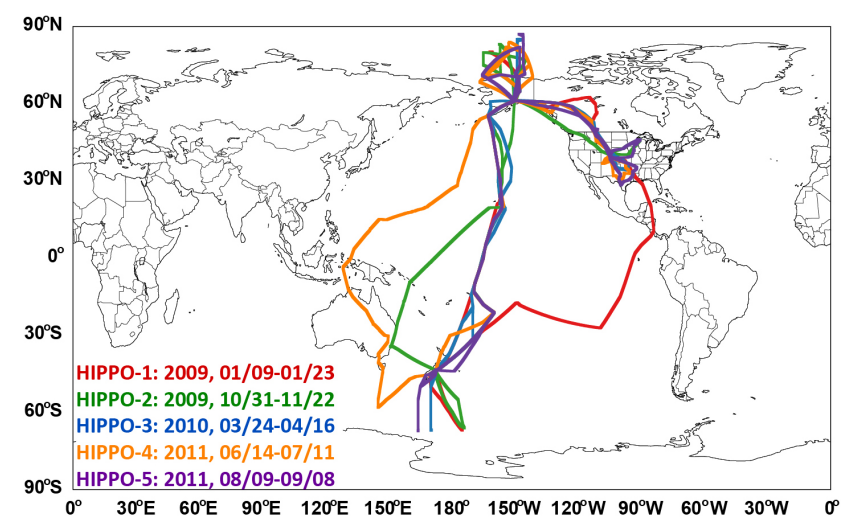

Figure 1. Times and flight tracks of five HIPPO campaigns. Our analysis is focused on $\mathrm{CO}$ over the Pacific Ocean.

2010; Guan et al., 2014; Lin et al., 2014). Atmospheric transport across the Pacific Ocean is studied extensively due to concerns on air quality over North America (Wuebbles et al., 2007; Lin et al., 2008a; Zhang et al., 2008; Cooper et al., 2010; Yu et al., 2012; Lin et al., 2014). Carbon monoxide (CO) is often used as a transport tracer because of its relatively long lifetime in the troposphere (1-3 months) (Liu et al., 2003; Liang et al., 2004; Zhang et al., 2008; Liu et al., 2013). Transport of CO and other pollutants to the Pacific Ocean is often measured by aircraft campaigns and satellite remote sensing (Liu et al., 2003; Zhang et al., 2008). The recent five High-performance Instrumented Airborne Platform for Environmental Research (HIAPER) Pole-to-Pole Observations (HIPPO) campaigns measured various atmospheric constituents over the Pacific from 2009 to 2011 (Wofsy, 2011; see Fig. 1 for flight tracks and times). They provide detailed information on the seasonal and vertical structures of CO over the Pacific (Kort et al., 2012), ideal for studying its spatiotemporal variability and for source attribution.

Analyses of global air pollution and transport are facilitated often by global chemical transport models (CTMs) that simulate various chemical, physical, and transport processes affecting air pollutants in the troposphere (Wild and Akimoto, 2001; Lin et al., 2008b; Zhang et al., 2008; Fiore et al., 2009; Liu et al., 2013; Lin et al., 2014). Global CTMs normally have a horizontal resolution of $200-500 \mathrm{~km}$ (Fiore et al., 2009; Lamarque et al., 2013), which is not able to capture nonlinear processes at various fine scales over the pollutant source regions. Over the past decades, nested CTMs with much increased horizontal resolutions have been developed by the global CTM community, e.g., GEOS-Chem (Chen et al., 2009) and the Transport Model, version 5 (TM5) (Krol et al., 2005), to better study air pollution characteristics over major pollutant source regions. For similar purposes, regional air quality models, such as the air quality model (AQM), the community multi-scale air quality model (CMAQ), and the Weather Research and Forecasting Model with Chemistry (WRF-Chem) model, have also been estab- lished with high horizontal resolutions (Huang et al., 2008; Lam and Fu, 2009; Pfister et al., 2011). These regional or nested models often obtain lateral boundary conditions (LBCs) of chemicals from global CTM simulations, and they capture many small-scale processes under-represented by global CTMs. However, the high-resolution simulation results are rarely used for feedback to improve global CTM simulations. Such a one-way combination of global and regional models does not allow for high-resolution regional models to help study the global air pollutant transport.

In this paper, we use the GEOS-Chem CTM simulations to analyze the tropospheric $\mathrm{CO}$ over the Pacific Ocean measured from the five HIPPO campaigns over 2009-2011. For this purpose, we develop a two-way coupler, the PeKing University CouPLer (PKUCPL), to integrate results of the global GEOS-Chem model (at $2.5^{\circ}$ long. $\times 2^{\circ}$ lat.) and its three nested models (at $0.667^{\circ}$ long. $\times 0.5^{\circ}$ lat.). These nested models cover Asia (Chen et al., 2009), North America (Zhang et al., 2011), and Europe (Vinken et al., 2014). These regions are main pollution source regions where smallscale nonlinear chemical and physical processes may have significant impacts on the global environment. The coupler acquires nested model results to replace global model results within the respective nested domains, in addition to letting the global CTM provide LBCs to the nested models. The coupler minimizes the computational cost of two-way integration by allowing the four models to run parallel to each other.

The rest of the paper is organized as follows. Section 2 describes the four GEOS-Chem models together with the two-way coupling framework. Section 3 presents an overall analysis of tropospheric CO simulated by the global CTM alone and by the two-way coupled model. Section 4 analyzes the tropospheric $\mathrm{CO}$ over the Pacific during the HIPPO campaigns, evaluating simulation results from the global model alone and the two-way coupled model. The analysis is focused on the seasonal and vertical variability of $\mathrm{CO}$, with important implications found for using the coarse-resolution global model to constrain CO emissions. Section 5 concludes the present study.

\section{GEOS-Chem and the two-way coupling framework}

\subsection{GEOS-Chem models}

Both the global and three nested GEOS-Chem CTMs (version 08-03-02; ) are driven by the GEOS-5 assimilated meteorological data from the National Aeronautic and Space Administration Global Modeling and Assimilation Office. The nested models are run at a horizontal resolution of $0.667^{\circ}$ long. $\times 0.5^{\circ}$ lat. which is native to the GEOS-5 data (see Fig. 2a for nested domains). The global model is run at a reduced resolution of $2.5^{\circ}$ long. $\times 2^{\circ}$ lat. with meteorological data regridded from the high-resolution GEOS- 5 data. All 
(a)

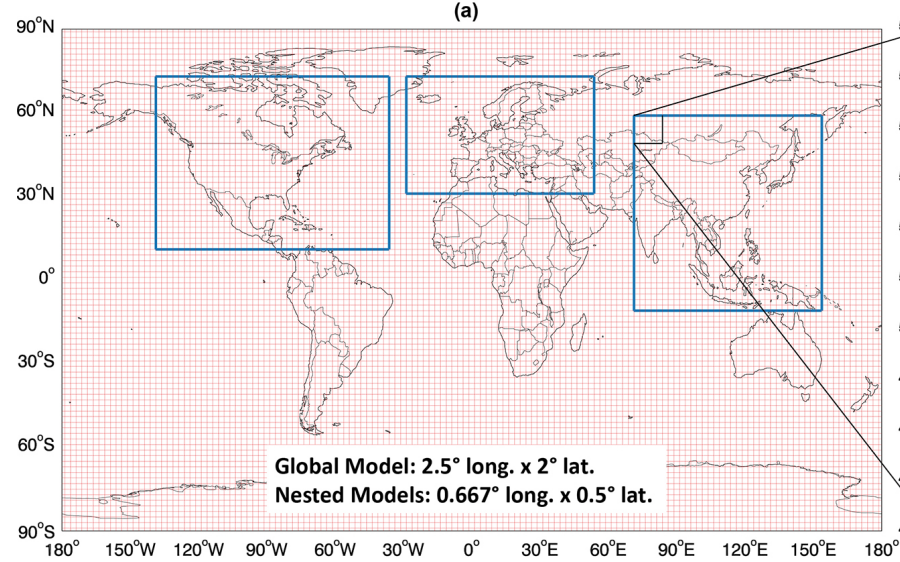

(b)

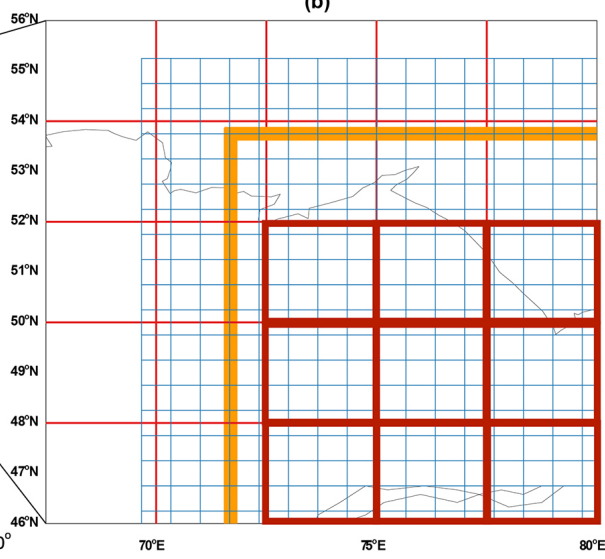

Figure 2. (a) Domains of three nested models covering Asia $\left(70-150^{\circ} \mathrm{E}, 11-55^{\circ} \mathrm{N}\right)$, North America $\left(140-40^{\circ} \mathrm{W}, 10-70^{\circ} \mathrm{N}\right)$ and Europe $\left(30-50^{\circ} \mathrm{E}, 30-70^{\circ} \mathrm{N}\right)$. (b) Illustration of how global and nested models exchange data in the northwestern corner of the Asian nested domain. Blue denotes nested model grids and red denotes global model grids. Thick yellow lines separate the buffer zone (three outer grid cells) and the inner domain of the nested model. To obtain LBCs, the nested model grid cells in the buffer zone adopt mixing ratios of chemicals from the global model. Global model results in the grid cells fully covered by the inner domain of the nested model (bounded by thickened red lines) are replaced with the nested model results after a mass-conversed regridding process.

models have 47 vertical layers extending from the surface up to $0.01 \mathrm{hPa}$ in a hybrid pressure-sigma coordinate, and the lowest 10 layers are each $\sim 130 \mathrm{~m}$ thick (see Appendix 3 at http://acmg.seas.harvard.edu/geos/doc/man/). The chemistry time step is $1 \mathrm{~h}$ in all models, while the transport time step is $15 \mathrm{~min}$ in the global model and $10 \mathrm{~min}$ in all nested models. Hereafter, we refer to the global model as the standalone global model and the two-way coupled model as the combined model system integrating the global model and all three nested models.

All models are run with the full $\mathrm{O}_{\mathrm{x}}-\mathrm{NO}_{\mathrm{x}}-\mathrm{VOC}-\mathrm{CO}-\mathrm{HO}_{\mathrm{x}}$ gaseous chemistry with online aerosol calculations. Model convection follows a modified relaxed Arakawa-Schubert scheme (Rienecker et al., 2008). Vertical mixing in the planetary boundary layer is parameterized with a non-local scheme (Holtslag and Boville, 1993; Lin and McElroy, 2010).

Global anthropogenic emissions of nitrogen oxides $\left(\mathrm{NO}_{\mathrm{x}}\right), \mathrm{CO}$, and non-methane volatile organic compounds (NMVOCs) are taken from the EDGAR 3.2-FT2000 (Emission Database for Global Atmospheric Research 3.2 Fast Track 2000) data set (Olivier et al., 2005). Emissions over Asia, North America, and Europe are further replaced by various regional inventories shown in Table 1. Emission data are available at $1^{\circ}$ long. $\times 1^{\circ}$ lat. or finer resolutions, and are regridded to model resolutions prior to the simulation of photochemistry. No interannual variability is imposed. Over Asia, temperature dependence is imposed upon residential emissions (Streets, 2003; Lin, 2012). Figure 3a shows that global annual anthropogenic emissions of $\mathrm{CO}$ amount to $\sim 590 \mathrm{Tg} \mathrm{yr}^{-1}$ with weak seasonality below $20 \%$. Note that for areas not replaced by regional inventories (mostly in the Southern Hemisphere), EDGAR 3.2-FT2000 CO emissions are $131 \mathrm{Tg} \mathrm{yr}^{-1}$, slightly larger than the value at $123 \mathrm{Tg} \mathrm{yr}^{-1}$ in the updated EDGAR v4.2 (Janssens-Maenhout et al., 2010) for 2008 (the latest year in EDGAR v4.2).

Monthly biomass burning emissions are taken from the GFED2 data set (van der Werf et al., 2006), with CO emissions updated to GFED3.1 (van der Werf et al., 2010). Figure $3 \mathrm{~b}$ shows that global monthly biomass burning emissions of CO vary between 6.3 and $96 \mathrm{Tg} \mathrm{month}^{-1}$ over the course of 2008-2011, depending on the climatic conditions. Over the nested domains (Fig. 3b), biomass burning emissions of $\mathrm{CO}$ vary more drastically with time.

Other emissions are calculated online, which are dependent on model meteorology and resolution. Lightning emissions of $\mathrm{NO}_{\mathrm{x}}$ are parameterized based on cloud heights (Price et al., 1997), with a local adjustment based on the optical transient detector and lightning imaging sensor (OTDLIS) satellite measurements (Sauvage et al., 2007; Murray et al., 2013) and a backward C-shape vertical profile (Ott et al., 2010). Soil emissions of $\mathrm{NO}_{\mathrm{x}}$ follow Yienger and Levy (1995) and Wang et al. (1998). Biogenic emissions of NMVOCs follow MEGAN (Model of Emissions of Gases and Aerosols from Nature) v2.1 (Guenther et al., 2006).

For 2009, global emissions from all sources used in the coarse-resolution global model are $\sim 45 \mathrm{Tg} \mathrm{N} \mathrm{yr}^{-1}$ for $\mathrm{NO}_{\mathrm{x}}$, and $587 \mathrm{TgC} \mathrm{yr}^{-1}$ for NMVOCs. Due to the resolutiondependent online calculation of biogenic NMVOC emissions and soil and lightning $\mathrm{NO}_{\mathrm{x}}$ emissions, the global all-source emissions in the two-way coupled model are larger than those in the global model by $5 \%$ for NMVOCs and by $1 \%$ for $\mathrm{NO}_{\mathrm{x}}$.

Figure 3c presents illustrative horizontal distributions of emissions over eastern China (part of the Asian nested domain). It shows that the spatial variability of emissions is much better resolved on the nested grid than on the global 
(a) Anthropogenic emissions

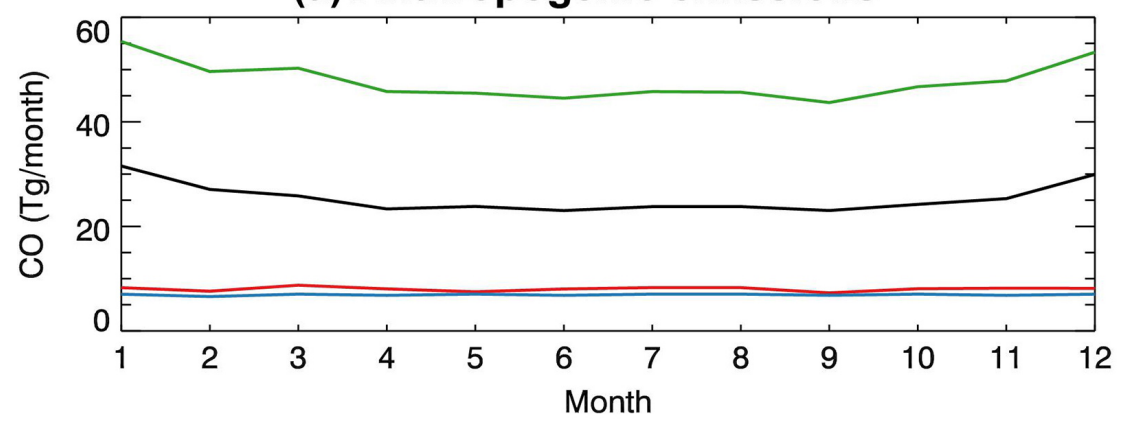

(b) Biomass burning emissions

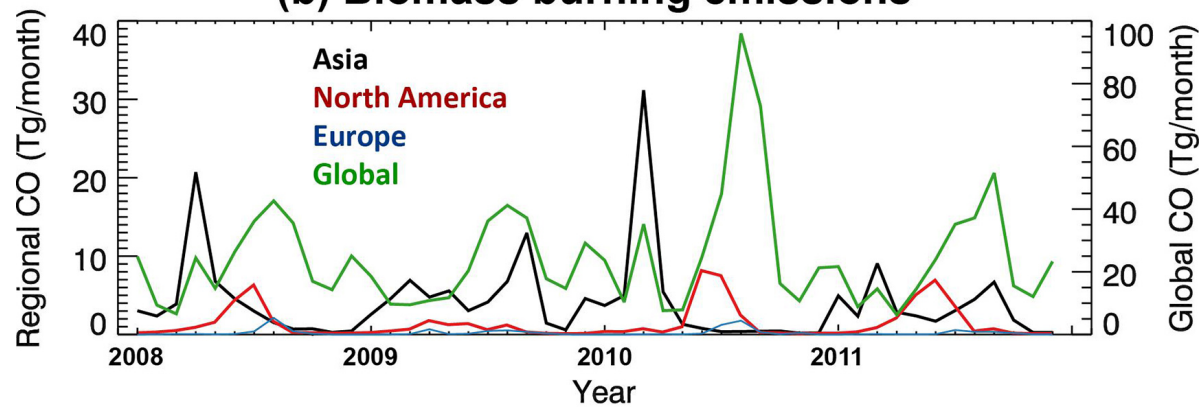

(c) Total emissions in 2009
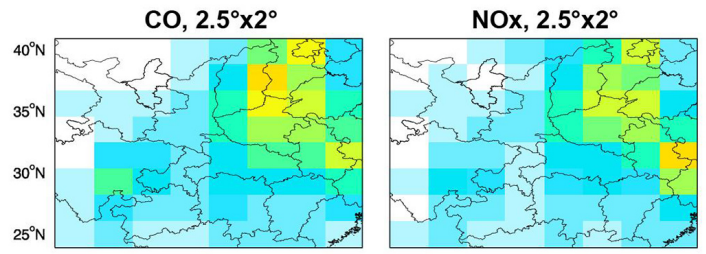

NMVOC, $2.5^{\circ} \times 2^{\circ}$
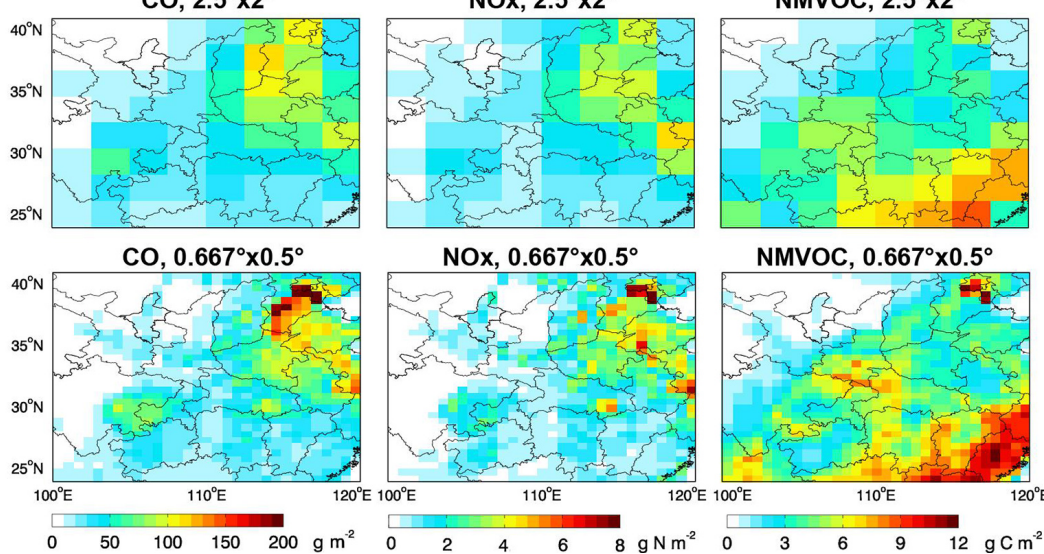

NMVOC, $0.667^{\circ} \times 0.5^{\circ}$

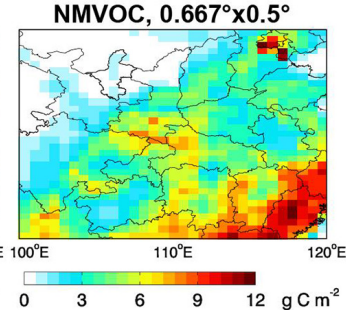

Figure 3. (a) Monthly anthropogenic (fossil + biofuel) emissions of $\mathrm{CO}$ within the nested or global model domains; emissions are unchanged from one year to another. (b) Monthly biomass burning emissions of CO over 2008-2011 within the nested or global model domains. (c) Spatial distributions of $\mathrm{CO}, \mathrm{NO}_{\mathrm{x}}$, and non-methane volatile organic compounds (NMVOCs) emissions from all sources in 2009 over eastern China on the global vs. nested grids.

grid. As detailed in Sect. 3.2, better resolved emissions contribute to a significantly improved simulation of $\mathrm{CO}$.

Simulations of both the global model and the two-way coupled model are conducted from July 2008 to 2011 to analyze the tropospheric CO during the HIPPO campaigns. Initial conditions of chemicals are regridded from a simulation at $5^{\circ}$ long. $\times 4^{\circ}$ lat. started from 2004. Simulations over July-December 2008 allow for a 6-month spin-up for our focused analysis over 2009-2011. Ancillary test simulations are also performed over shorter periods (from July 2008 to January or to December 2009) to elaborate the physical mechanisms affecting the $\mathrm{CO}$ simulation under the two-way coupling framework.

\subsection{Two-way coupling setup}

Figure 4 shows the flowchart of the global and nested model coupling process. All models are regulated by the PKUCPL coupler. The coupler determines when and how to output global model results to update the LBCs of nested models, 
Table 1. Anthropogenic and biomass burning emission inventories used by GEOS-Chem.

\begin{tabular}{|c|c|c|c|c|}
\hline $\begin{array}{l}\text { Source } \\
\text { type }\end{array}$ & Region & Data set & Resolution $^{1}$ & References and notes \\
\hline \multirow[t]{6}{*}{ Anthro. } & Global & $\begin{array}{l}\text { EDGAR } \\
\text { 3.2-FT2000 }\end{array}$ & $1^{\circ}$ long. $\times 1^{\circ}$ lat. & Olivier et al., 2005 \\
\hline & Asia & INTEX-B & $0.5^{\circ}$ long. $\times 0.5^{\circ}$ lat. & Zhang et al., 2009 \\
\hline & US & NEI05 & $4 \mathrm{~km} \times 4 \mathrm{~km}$ & $\begin{array}{l}\text { http://www.epa.gov/ttn/chief/net/2005inventory. } \\
\text { html\#inventorydata } \\
\text { Gridded data were adopted from WRF-Chem } \\
\text { (ftp://aftp.fsl.noaa.gov/divisions/taq/emissions_ } \\
\text { data_2005) }\end{array}$ \\
\hline & Canada & $\mathrm{CAC}$ & $1^{\circ}$ long. $\times 1^{\circ}$ lat. & http://www.ec.gc.ca/pdb/cac/cac_home_e.cfm \\
\hline & Mexico & BRAVO & $1^{\circ}$ long. $\times 1^{\circ}$ lat. & Kuhns et al., 2003 \\
\hline & Europe & EMEP & $0.5^{\circ}$ long. $\times 0.5^{\circ}$ lat. & Auvray and Bey, 2005 \\
\hline $\begin{array}{l}\text { Biomass } \\
\text { burning }\end{array}$ & Global & $\begin{array}{l}\text { GFED2; } \\
\text { GFED3.1 }\end{array}$ & $1^{\circ}$ long. $\times 1^{\circ}$ lat. & $\begin{array}{l}\text { van der Werf et al., 2006; } 2010 \\
\text { GFED3.1 for CO and GFED2 for others }\end{array}$ \\
\hline
\end{tabular}

${ }^{1}$ Before re-gridded to model resolutions.

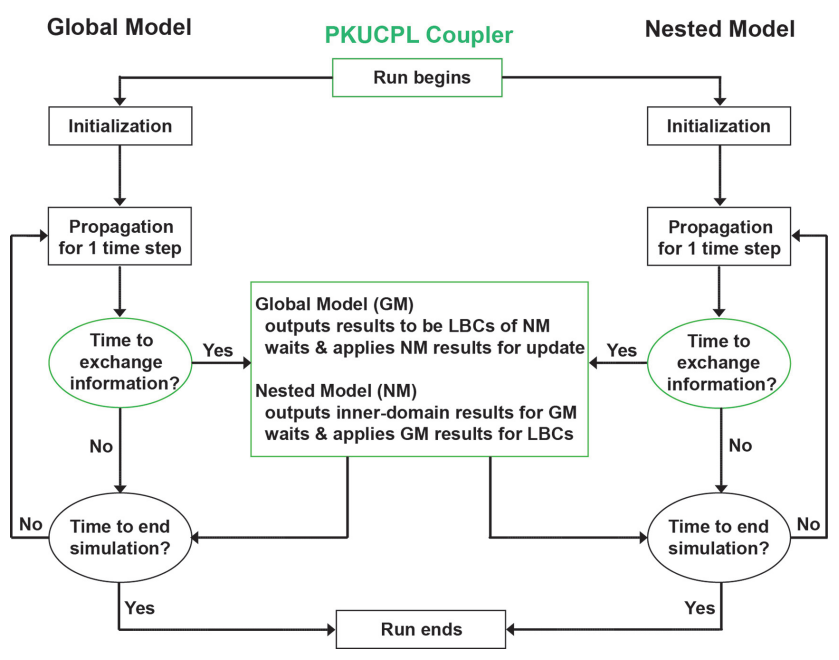

Figure 4. Flowchart of the two-way coupling process. Green indicates the key steps to achieve the two-way integration via the PKUCPL coupler.

and to output nested model results to adjust the global model. Information of all chemical species is exchanged every $3 \mathrm{~h}$ between the global and nested models. At the time step for information exchange, the propagation of a particular model is paused until all relevant information has been updated.

Figure $2 b$ illustrates the global and nested model grid cells for information exchange. For a nested model, a buffer zone consisting of three nested grid cells is implemented on each edge of the nested domain (Fig. 2b). At the time of updating LBCs, mixing ratios of all chemical species in the buffer zone are taken directly from the respectively grid cells of the global model. A more detailed description of the LBC setups can be found in Chen et al. (2009). While providing the LBCs, global model results in the troposphere are replaced by nested model results within the respective nested domains. Specifically, mass concentrations of all chemical species are output from nested models, regridded horizontally to match the global model grid with mass conservation guaranteed, and then used to replace global model results in the troposphere. Global model grid cells overlapping with the buffer zone of a nested model are not adjusted (Fig. 2b). To guarantee mass conservation in the horizontal regridding process, pollutant mass in a nested grid cell is calculated and then allocated to global grid cells based on the fraction of the area of the nested grid cell belonging to a given global grid cell.

Under the two-way coupling framework, all models proceed in parallel. The wall-clock time of the coupled system is greater than the slowest individual model (the nested model for North America) by only $10 \%$; the additional time is used for information exchange between models. With an eightcore (Intel(R) Xeon(R) CPU X7550 at 2.00 GHz) OpenMP parallelization for each global or nested model, the coupled system takes about 10 days to finish one simulation year.

\subsection{Testing the accuracy of the two-way coupling}

Several issues warrant considerations for the two-way coupling. First, the coupled simulation may be affected by the frequency of inter-model data exchange. We find that increasing the exchange frequency from every $3 \mathrm{~h}$ to every $1 \mathrm{~h}$ does not affect the $\mathrm{CO}$ simulation after the 6-month spin-up period.

In addition, our treatment of LBCs is relatively simplified as the horizontal fluxes of chemicals (Krol et al., 2005) are not accounted for explicitly. This introduces certain random perturbations to the nested models that might in turn affect the global simulation in the two-way coupled system. We thus conduct a test two-way coupled simulation that successively increases the LBCs by $5 \%$ for all chemical species at 

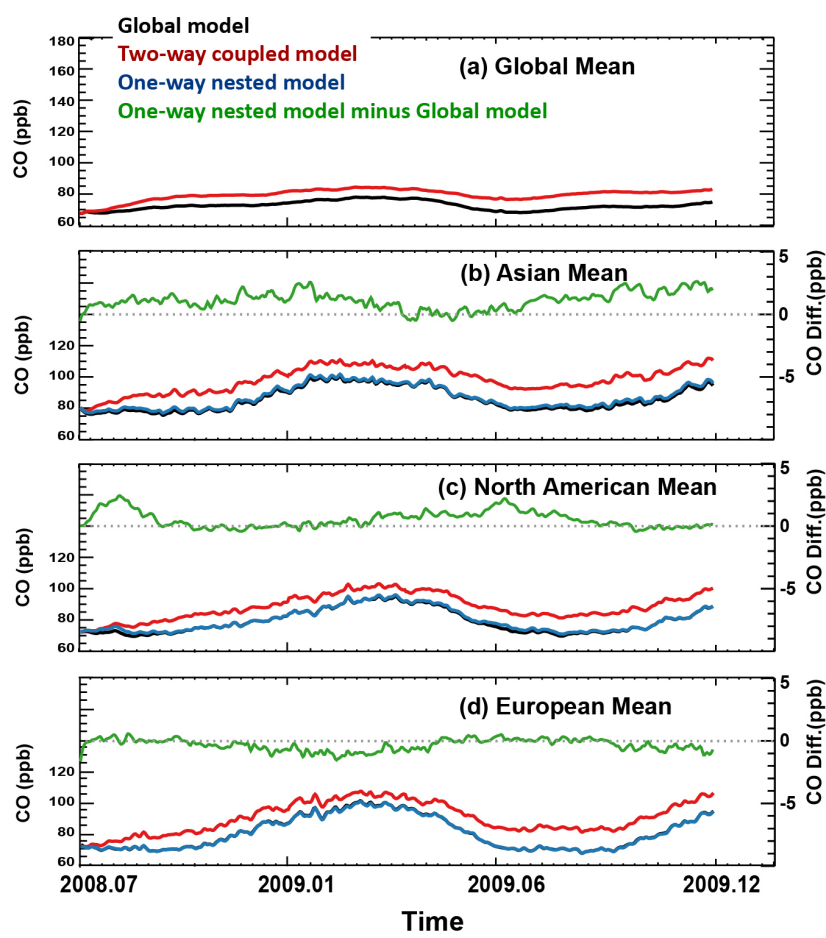

Figure 5. Daily mean tropospheric mean CO mixing ratio from July 2008 to December 2009 averaged over the global or nested model domains simulated by the global model alone (black), by the twoway coupled model (red), and by the one-way nested model (blue; with no feedbacks to the global model; only for nested domains). Also shown in (b-d) is the difference between the one-way nested and the global model (green; right axis).

an exchange time step and then decreases the LBCs by $5 \%$ at the next time step. We find that, even with such a large perturbation, the test simulation reproduces the two-way coupled simulation without the $5 \%$ perturbation after the 6-month spin-up period.

Furthermore, mass conservation is required in regridding the nested model results to modify the global model. To address the mass conservation issue, we conduct additional test simulations by turning off all source and sink processes in both the global model and the two-way coupled model. Since the two simulations use the same initial conditions and only simulate the transport processes, mass conservation means that the total atmospheric content of $\mathrm{CO}$ should be the same between the global model and the two-way coupled model. Indeed, the test two-way coupled simulation reproduces the $\mathrm{CO}$ content simulated by the test global model.

\section{General comparisons of tropospheric $\mathrm{CO}$ and hydroxyl radical simulated by the two-way coupled model vs. the global model}

Figure 5 compares the day-to-day variations of tropospheric mean CO mixing ratios from July 2008 to December 2009 simulated by the global model (black lines) vs. the twoway coupled model (red lines). The spin-up period of JulyDecember 2008 is included to elaborate the propagation differentiating the global model simulation from the two-way coupled simulation. In the three nested domains (Fig. 5bd), the tropospheric mean $\mathrm{CO}$ simulated by the global model varies from $70 \mathrm{ppb}$ to $115 \mathrm{ppb}$ over the $1.5 \mathrm{yr}$ period. $\mathrm{CO}$ reaches a maximum in the Northern Hemisphere winterspring with a minimum in summer, reflecting the seasonal variation in CO sources and lifetime (Liang et al., 2004). The two-way coupled model produces more $\mathrm{CO}$ than the global model; the difference in 2009 is about $12.9 \mathrm{ppb}(13.9 \%)$ averaged over Asia, $8.9 \mathrm{ppb}(11.2 \%)$ over North America, and $9.4 \mathrm{ppb}(11.7 \%)$ over Europe.

Globally (Fig. 5a), CO mixing ratios in 2009 simulated by the two-way coupled model are about $7.4 \mathrm{ppb}(10.4 \%)$ higher than those simulated by the global model alone. The enhancement is more significant in the Northern Hemisphere $(13.3 \%)$, which alleviates the negative bias over the Northern Hemisphere typical for coarse-resolution global models (Naik et al., 2013). The enhancement is smaller in the Southern Hemisphere (6.9\%).

Table 2 further shows the CO budget in 2009. The tropospheric CO loss simulated by the two-way coupled model is close to that simulated by the global model. This is due to the decrease in hydroxyl radical $(\mathrm{OH})$ content (see Sect. 3.3) compensating for the enhancement in $\mathrm{CO}$. However, the mean tropospheric lifetime of $\mathrm{CO}$ (burden divided by loss) is enhanced by $9.0 \%$, from 1.75 months to 1.91 months.

\subsection{Accumulation of small differences differentiates the two-way coupled simulation from the global model}

To elucidate how the difference between the two-way coupled model and the global model accumulates, we also conduct simulations with one-way nested models (i.e., no feedbacks to the global model; blue lines in Fig. 5b-d). CO concentrations simulated by the one-way nested models differ slightly from global model results on any given day, but the difference varies from one day to another (as evident from the green lines). On average, the one-way nested models produce daily mean $\mathrm{CO}$ higher than the global model by $1.24 \mathrm{ppb}$ over Asia and $0.68 \mathrm{ppb}$ over North America and lower by $0.15 \mathrm{ppb}$ over Europe. Here, the nested models adopt LBCs from the global model every $3 \mathrm{~h}$ with no influences on the global model; thus, the $\mathrm{CO}$ difference cannot be accumulated effectively throughout time. With the two-way coupling (red lines), however, these regional differences are used to modify 
Table 2. Global budget of tropospheric CO for 2009.

\begin{tabular}{lcc}
\hline & Global model & Two-way coupled model \\
\hline Loss by OH reaction $\left(\mathrm{Tg} \mathrm{yr}^{-1}\right)$ & 2364 & 2400 \\
Transport to stratosphere $\left(\mathrm{Tg} \mathrm{yr}^{-1}\right)$ & 2.8 & 3.3 \\
Production from methane and NMVOC oxidation $\left(\mathrm{Tg} \mathrm{yr}^{-1}\right)$ & 1465 & 1497 \\
Emissions $\left(\mathrm{Tg} \mathrm{yr}^{-1}\right)$ & $913^{*}$ & $917^{*}$ \\
Fossil + biofuel & 585 & 589 \\
Biomass burning & 328 & 328 \\
Burden (Tg) & 346 & 383 \\
Tropospheric lifetime (month) & 1.75 & 1.91 \\
\hline
\end{tabular}

* The slight difference of $4 \mathrm{Tg} \mathrm{yr}^{-1}$ (i.e., 913 vs. 917 ) is related to the treatment of various offline anthropogenic emission inventories; the effect on $\mathrm{CO}$ concentrations is negligible since such a emission difference is less than $0.2 \%$ of total $\mathrm{CO}$ sources.

(a) HIPPO Measurements

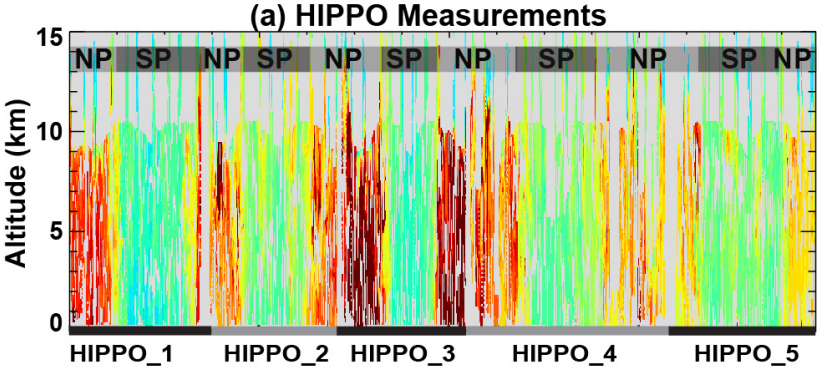

(b) Global Model

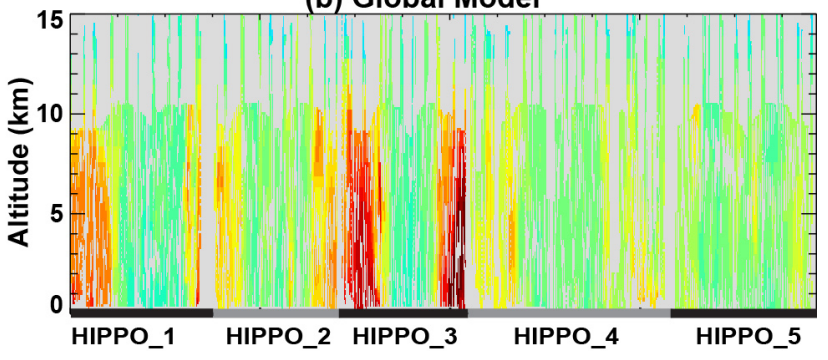

(c) Two-Way Coupled Model

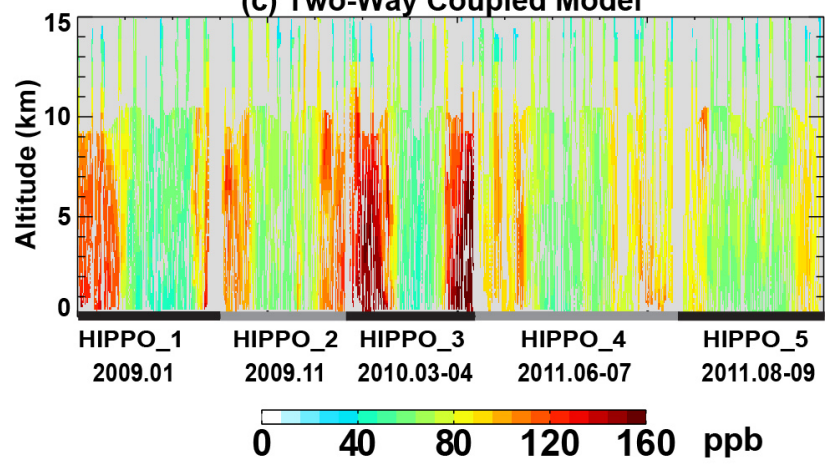

Figure 6. Measured and modeled vertical distributions of tropospheric $\mathrm{CO}$ along the flight tracks of HIPPO campaigns. Grey denotes times and locations with no HIPPO data. Data over the North Pacific (NP) and South Pacific (SP) are distinguished in (a). the global model every $3 \mathrm{~h}$ and, with the long lifetime of $\mathrm{CO}$, are accumulated and carried across the globe.

Figure 5d shows that over Europe, the one-way nested model (blue line) results in lower CO than the global model (black line), while the two-way coupled model (red line) produces higher $\mathrm{CO}$ than the global model. This is due to the elevated transport of $\mathrm{CO}$ produced in Asia and North America via the two-way coupling mechanism. Such interaction between high-resolution simulations in multiple regions has been unexplored previously and warrants further research.

\subsection{Factors differentiating the two-way coupled model from the global model}

Table 3 identifies various factors differentiating the two-way coupled model from the global model, taking the simulated CO in January 2009 for analysis. In January 2009, the global tropospheric mean $\mathrm{CO}$ simulated by the two-way coupled model is larger than that simulated by the global model by $9.6 \%$. Various test simulations are conducted from July 2008 to January 2009 to help delineate the differentiating factors. As shown below, the contributions of these factors are derived in a linear manner as a first-order estimate. The contributions of these factors may be different in other months and years as a result of changes in emissions, meteorology, and chemical reactivity; moreover, further research is needed for more systematic evaluation.

First, the magnitude of emissions differs between the two simulations. As shown in Sect. 2.1, due to changes in online emissions, global total emissions are larger in the twoway coupled model than in the global model by $5 \%$ for NMVOCs and by $1 \%$ for $\mathrm{NO}_{\mathrm{x}}$. The additional NMVOC emissions increase the tropospheric $\mathrm{CO}$, whereas the extra $\mathrm{NO}_{\mathrm{x}}$ emissions have a negative impact on $\mathrm{CO}$ (by increasing the $\mathrm{OH}$ content). A test simulation with the global model adopts all emissions in the nested domains from the two-way coupled model at every time step, via a mass-conserved gridconversion process. The test simulation increases the tropospheric CO in January 2009 by $3.5 \%$ compared to the standard global model (Table 3 ), roughly representing the effect 
Table 3. Percentage contributions of individual factors to the difference in January 2009 tropospheric CO between the two-way coupled model and the global model, after a 6-month spin-up from July 2008 with consistent initial conditions of chemicals.

\begin{tabular}{ll}
\hline Factors & $\%$ contribution \\
\hline All factors & $9.6 \%$ \\
A. Emission magnitude (mainly related to biogenic NMVOCs) & $3.5 \%$ \\
B. Nonlinear processes within the troposphere & $6.1 \%$ \\
B1. Small-scale variability in emissions of $\mathrm{NO}_{\mathrm{x}}, \mathrm{NMVOCs,} \mathrm{CO}$, etc. & $4.6 \%$ \\
B2. Non-emission small-scale processes & $1.5 \%$ \\
\hline
\end{tabular}

A. Obtained by contrasting simulations of the global model with vs. without adopting the nested model emissions at individual time steps; emissions are regridded from the nested to coarse resolution.

B. Residual of all factors subtracting A.

B1. Residual of B subtracting B2, as driven by small-scale horizontal distributions of emissions resolved on the nested grid but not on the coarse global grid.

B2. Obtained by contrasting simulations of the two-way coupled model with versus without adopting the global model emissions at individual time steps; emissions are regridded from the coarse to nested resolution, and are thus resolved only at the scale of the coarse grid.

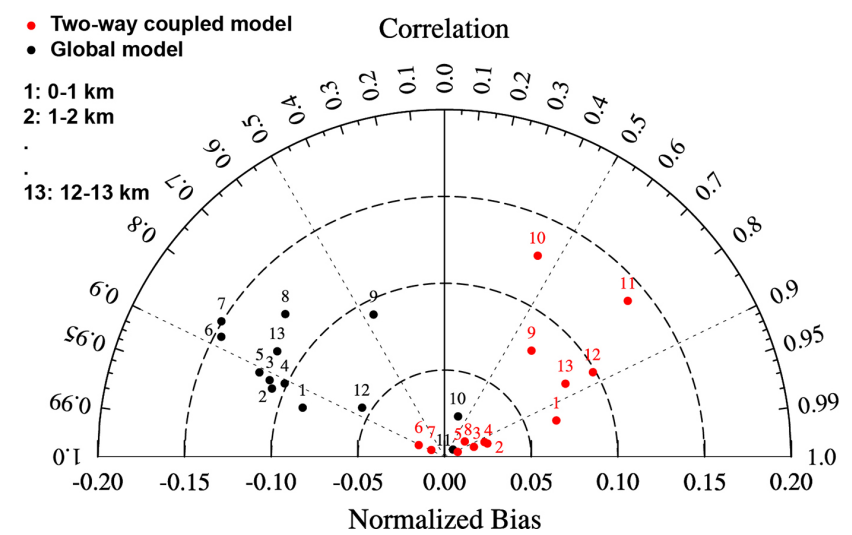

Figure 7. Correlation and mean normalized bias of modeled CO with respect to HIPPO measurements throughout the HIPPO campaigns, for individual vertical layers (e.g., $0-1 \mathrm{~km}, 1-2 \mathrm{~km}$ ).

of differences in emission magnitude between the two-way coupled model and the global model. The residual difference of $6.1 \%$ (i.e., $9.6 \%$ minus $3.5 \%$ ) represents the combined effect of all factors other than emission magnitude.

Furthermore, the two-way coupled model better captures the small-scale spatial variability of $\mathrm{NO}_{\mathrm{x}}, \mathrm{NMVOCs}$, and $\mathrm{CO}$ concentrations in the nested domains with a consequence on the photochemical efficiency. For example, the efficiency of $\mathrm{NO}_{\mathrm{x}}$ in producing ozone (and thus affecting $\mathrm{OH}$ and $\mathrm{CO}$ ) highly depends on its abundance relative to NMVOCs and $\mathrm{CO}$. Decreasing the horizontal resolution leads to more significant artificial mixing of $\mathrm{NO}_{\mathrm{x}}, \mathrm{NMVOCs}$, and $\mathrm{CO}$ with a resulting effect on its photochemical efficiency. In our study, the spatial variability in concentration is driven by the variability in emissions (see Fig. 3c for example), since the twoway coupled model uses the same initial conditions as the global model. To derive the effect of small-scale emission variability, we conduct a test simulation of the two-way coupled model by adopting all emissions from the global model at every time step. Here, emissions are regridded from $2.5^{\circ}$ long. $\times 2^{\circ}$ lat. to $0.667^{\circ}$ long. $\times 0.5^{\circ}$ lat. in the nested domains such that horizontal variability at scales smaller than $2.5^{\circ}$ long. $\times 2^{\circ}$ lat. is not resolved. As a result, the test twoway coupled simulation produces higher $\mathrm{CO}$ by $1.5 \%$ than the standard global model in January 2009 . The $1.5 \%$ difference represents the combined effect of non-emission smallscale variability (related to vertical transport, radiation, and other resolution-dependent processes) that is resolved on the $0.667^{\circ}$ long. $\times 0.5^{\circ}$ lat. grid but not on the $2.5^{\circ}$ long. $\times 2^{\circ}$ lat. grid. Therefore, the effect of small-scale variability in $\mathrm{NO}_{\mathrm{x}}$, NMVOCs, and $\mathrm{CO}$ emissions (which greatly determine their concentration variability) is estimated at $4.6 \%$ (i.e., $6.1 \%$ minus $1.5 \%$ ), contributing about half of the difference between the two-way coupled model and the global model.

\subsection{Impacts on tropospheric $\mathrm{OH}$ abundance and methyl chloroform lifetime (MCF)}

Table 4 shows the impacts of two-way coupling on the tropospheric $\mathrm{OH}$ budget. Consistent with the increased $\mathrm{CO}$ content, the air mass weighted global mean tropospheric $\mathrm{OH}$ in 2009 simulated by the two-way coupled model is lower than that simulated by the global model by $4.2 \%$ $\left(11.9 \times 10^{5}\right.$ vs. $12.4 \times 10^{5}$ molec cm $\left.^{-3}\right)$. The $4.2 \%$ difference exceeds the standard deviation of $\mathrm{OH}$ interannual variation estimated at $2.3 \%$ (Montzka et al., 2011). The $\mathrm{OH}$ reduction is more significant in the Northern Hemisphere $(5.7 \%)$ than in the Southern Hemisphere $(2.1 \%)$, reducing the northern-southern hemispheric $\mathrm{OH}$ ratio from 1.27 to 1.24. This change helps alleviate the overestimation in hemispheric $\mathrm{OH}$ contrast typical for coarse-resolution global CTMs (Naik et al., 2013); however, the production and loss rates of $\mathrm{OH}$ are affected insignificantly (Table 4). For example, the loss via $\mathrm{OH}+\mathrm{CO}$ reaction changes marginally due to the increased $\mathrm{CO}$ concentration compensating for the decreased $\mathrm{OH}$. 
Table 4. Global budget of tropospheric $\mathrm{OH}$ for 2009.

\begin{tabular}{lll}
\hline & Global model $^{1}$ & Two-way coupled model $^{1}$ \\
\hline Total loss $\left(\mathrm{Tg} \mathrm{yr}^{-1}\right)$ & 3780 & 3756 \\
$\mathrm{OH}+\mathrm{CO}$ & $1440(38 \%)$ & $1452(38 \%)$ \\
$\mathrm{OH}+\mathrm{CH}_{4}^{2}$ & $540(14 \%)$ & $516(14 \%)$ \\
$\mathrm{OH}+\mathrm{NMVOCs}^{2}$ & $840(22 \%)$ & $852(23 \%)$ \\
$\mathrm{OH}+\mathrm{O}_{3}$ & $204(5 \%)$ & $204(5 \%)$ \\
$\mathrm{OH}+\mathrm{HO}_{\mathrm{y}}$ & $396(10 \%)$ & $384(10 \%)$ \\
$\mathrm{OH}+\mathrm{NO}_{\mathrm{y}}$ & $72(2 \%)$ & $60(2 \%)$ \\
$\mathrm{OH}+\mathrm{H}_{2}, \mathrm{SO}_{2}$, etc. & $132(9 \%)$ & $132(8 \%)$ \\
Total production $\left(\mathrm{Tg} y r^{-1}\right)$ & 3780 & 3756 \\
Photolysis of $\mathrm{O}_{3}$ & $1608(43 \%)$ & $1584(42 \%)$ \\
$\mathrm{Photolysis}$ of other species & $480(12 \%)$ & $504(14 \%)$ \\
$\mathrm{Reactions}$ & $1692(45 \%)$ & $1668(44 \%)$ \\
Air mass weighted mean concentration $\left(10^{5} \mathrm{~cm}^{-3}\right)$ & 12.4 & 11.9 \\
MCF loss rate weighted mean concentration $\left(10^{5} \mathrm{~cm}^{-3}\right)$ & 12.5 & 12.1 \\
Methyl chloroform lifetime $(\mathrm{yr})^{3}$ & 5.3 & 5.5 \\
\hline
\end{tabular}

${ }^{1}$ In the parentheses is the percentage contribution to total loss or production.

${ }^{2}$ In the simulations, the tropospheric mixing ratio of methane $\left(\mathrm{CH}_{4}\right)$ is fixed at the 2007 level $\left(1732.5 \mathrm{ppb}\right.$ south of $30^{\circ} \mathrm{S}, 1741.7 \mathrm{ppb}$ between $30^{\circ} \mathrm{S}$ and Equator, $1801.4 \mathrm{ppb}$ between Equator and $30^{\circ} \mathrm{N}$, and $1855.6 \mathrm{ppb}$ north of $\left.30^{\circ} \mathrm{N}\right)$.

${ }^{3} \mathrm{Via}$ the reaction with tropospheric $\mathrm{OH}$, defined as $0.92 \cdot \sum_{i=1}^{\mathrm{T}+\mathrm{S}}\left(\Delta P_{i} \cdot A\right) / \sum_{i=1}^{\mathrm{T}}\left(\kappa_{i} \cdot \Delta P_{i} \cdot C_{i} \cdot A\right)$, where $i$ denotes a layer, T the troposphere, $\mathrm{S}$ the stratosphere, $\Delta P_{i}$ the delta air pressure, $\kappa_{i}$ the reaction constant, $C_{i}$ the $\mathrm{OH}$ concentration, and $A$ the area occupied by a grid cell. The coefficient of 0.92 accounts for the vertical gradient of methyl chloroform mixing ratio (Prather et al., 2012). The horizontal and time dimensions are omitted from the equation for simplicity.

The reduced $\mathrm{OH}$ abundance leads to an enhanced lifetime of methyl chloroform via tropospheric $\mathrm{OH}$ from $5.3 \mathrm{yr}$ to $5.5 \mathrm{yr}$, a $4.2 \%$ increase. The enhanced lifetime is closer to the observation-based estimate at 6.0-6.3 yr (Prinn et al., 2005; Prather et al., 2012).

\section{Evaluation of simulated $\mathrm{CO}$ over the Pacific during the five HIPPO campaigns}

\subsection{Selection of HIPPO CO data and coincident model results}

Figure 1 shows the flight tracks and dates of five HIPPO aircraft campaigns conducted in various seasons between 2009 and 2011. These campaigns were designed to measure atmospheric trace constituents in the remote troposphere over the Pacific, Arctic, and near-Antarctic regions (Wofsy, 2011). In these campaigns, aircrafts took off in central North America, flew northward to almost $85^{\circ} \mathrm{N}$, turned southward until $75^{\circ} \mathrm{S}$, and finally went back to North America. The measurements provide a large quantity of global-scale high-quality data for analysis of atmospheric chemistry in these remote areas.

During HIPPO, CO was measured by direct absorption spectroscopy using the Harvard University/Aerodyne Research Quantum Cascade Laser Spectrometer (Jimenez et al., 2005; Kort et al., 2012). To evaluate GEOS-Chem simulations, this study uses the merged data set providing the tropospheric $\mathrm{CO}$ mixing ratios at a vertical resolution of $0.1 \mathrm{~km}$ (see http://hippo.ornl.gov/node/16). A total of 620 vertical profiles over the Pacific Ocean are employed, with 124 profiles from HIPPO-1, 98 from HIPPO-2, 103 from HIPPO-3, 143 from HIPPO-4, and 152 from HIPPO-5. Model results for $\mathrm{CO}$ are sampled at the times and locations of individual measurements to ensure spatiotemporal consistency with the HIPPO data. In particular, model results in the grid box encompassing the location (longitude, latitude, and altitude) of a given measurement are used for comparison with the observation.

\subsection{General spatiotemporal pattern of the Pacific CO during HIPPO}

Figure 6a shows the time-height distribution of CO mixing ratios over the Pacific measured from the five campaigns. Most measurements are concentrated below $10 \mathrm{~km}$, especially below $9 \mathrm{~km}$. Below $10 \mathrm{~km}$, CO normally exceeds $80 \mathrm{ppb}$ at the beginning and end of each campaign measured over the North Pacific, with values normally lower than $70 \mathrm{ppb}$ measured over the South Pacific (Wofsy, 2011). The hemispheric contrast is due mainly to the larger sources of $\mathrm{CO}$ in the Northern Hemisphere.

Figure 6a shows that the measured North Pacific CO mixing ratios reach a maximum during HIPPO-3 in March-April 2010. This reflects in part the strong Asian biomass burning emissions in the period (Fig. 3b). Asian influences are also enhanced in spring because of increased midlatitude cyclonic activity supplemented by a relatively long lifetime of CO (Liu et al., 2003; Liang et al., 2004). By comparison, the 
(a) HIPPO-1: 2009.01

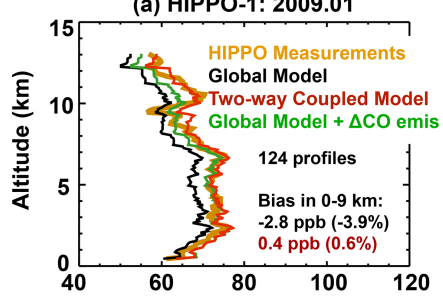

(c) HIPPO-3: 2010.03-2010.04

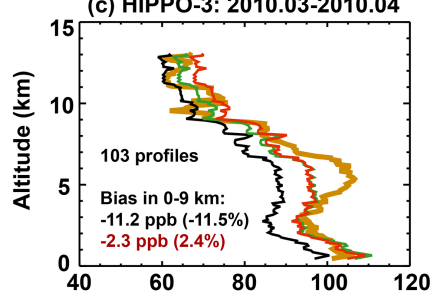

(e) HIPPO-5: 2011.08-2011.09
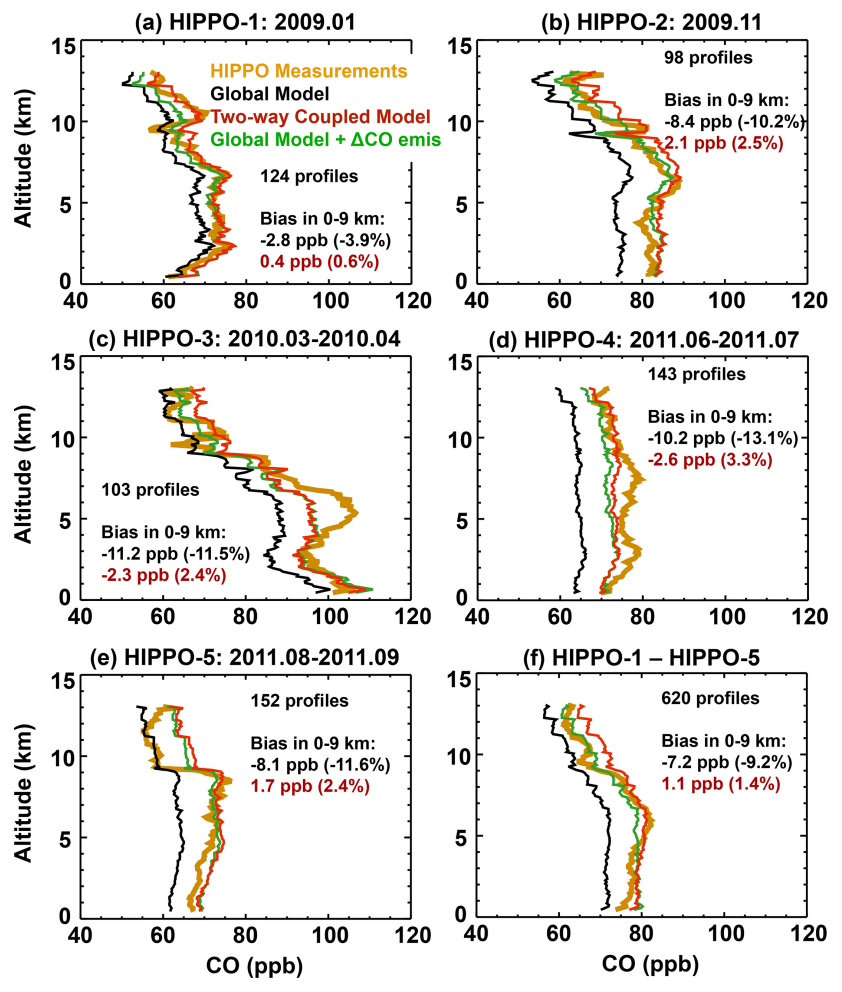

(d) HIPPO-4: 2011.06-2011.07

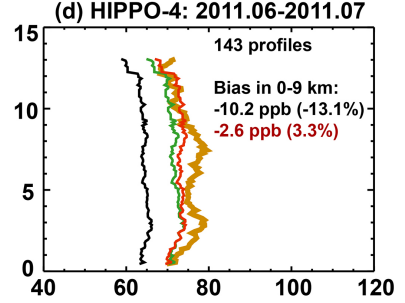

(f) HIPPO-1 - HIPPO-5

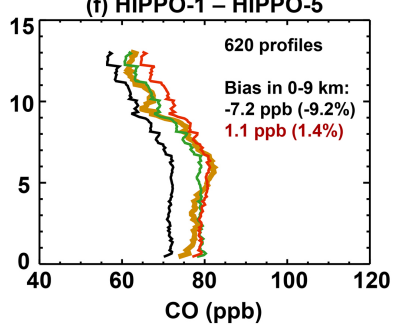

Figure 8. Measured and simulated vertical profiles of CO at $0.1 \mathrm{~km}$ intervals averaged over (a-e) individual and (f) all HIPPO campaigns. Model results are sampled at times and locations coincident to HIPPO measurements. Green lines represent global model simulations with increased global $\mathrm{CO}$ emissions that roughly resemble the two-way coupled simulation (especially below $4 \mathrm{~km}$ ); increases in CO emissions are $15 \%$ for HIPPO-1, $25 \%$ for HIPPO-2, $15 \%$ for HIPPO-3, $25 \%$ for HIPPO-4, and $35 \%$ for HIPPO-5. Also shown are the number of profiles and mean model biases below $9 \mathrm{~km}$ (with abundant measurements).

North Pacific CO mixing ratios are the lowest during HIPPO4 and HIPPO-5 over June-September 2011 when the lifetime of CO reaches a minimum (Liang et al., 2004).

Figure $6 \mathrm{~b}$ and $\mathrm{c}$ show that both the global model and the two-way coupled model reproduce the general spatiotemporal structure of HIPPO CO. However, the two-way coupled simulation is closer to HIPPO CO than the global model, particularly for the high values over the North Pacific. The mean bias in the two-way coupled model is only $1.1 \mathrm{ppb}(1.4 \%)$ below $9 \mathrm{~km}$, with a bias of $-1.8 \mathrm{ppb}(-2.3 \%)$ for the North Pacific and $2.6 \mathrm{ppb}(3.3 \%)$ for the South Pacific. The global model generally underestimates HIPPO CO with a mean bias by $-7.2 \mathrm{ppb}(-9.2 \%)$ below $9 \mathrm{~km}$; the bias is much larger over the North Pacific $(-10.2 \mathrm{ppb},-13.1 \%)$ than over the South Pacific $(-1.6 \mathrm{ppb},-2.1 \%)$. Such a negative bias in the Northern Hemisphere is typical for coarse-resolution global CTMs (Naik et al., 2013).

Figure 7 further evaluates the simulated $\mathrm{CO}$ mixing ratios in each vertical layer with a thickness of $1 \mathrm{~km}$ (layer 1
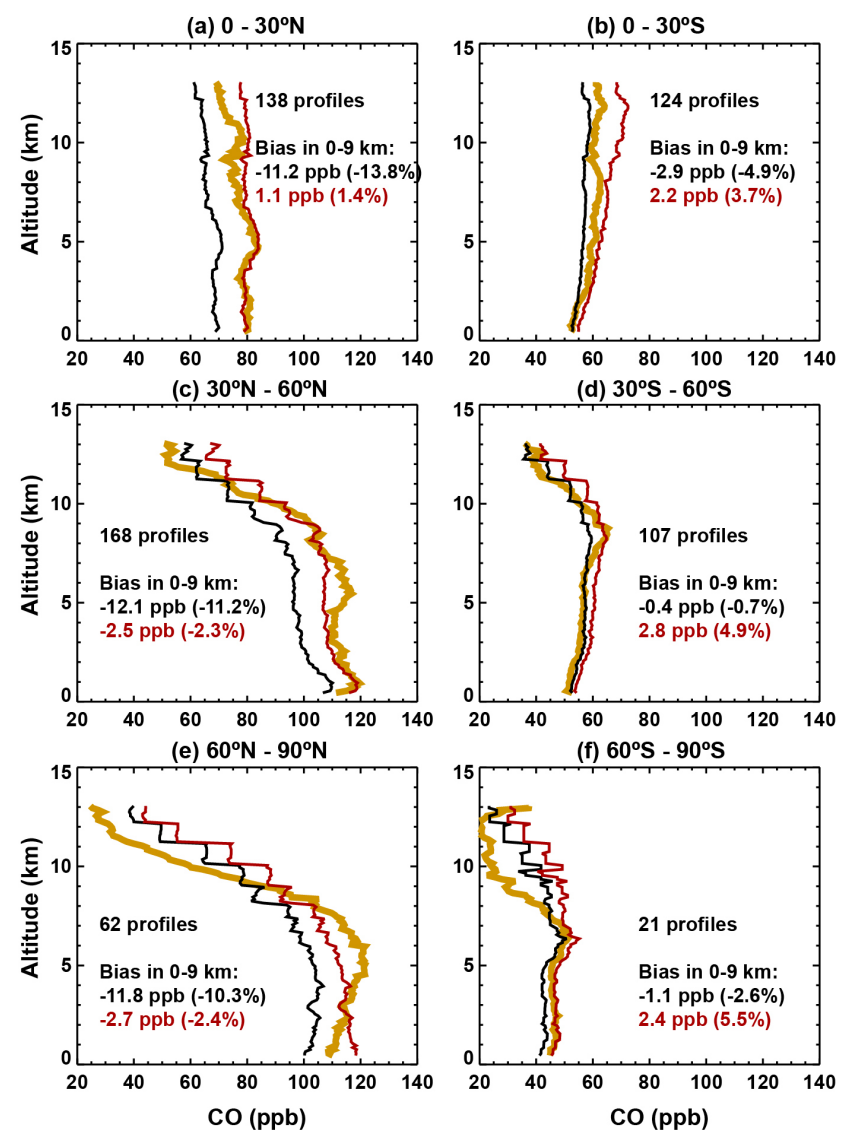

Figure 9. Measured and simulated vertical profiles of $\mathrm{CO}$ at $0.1 \mathrm{~km}$ intervals averaged across all HIPPO campaigns at the six latitude bands of $30^{\circ}$ width. Model results are sampled at times and locations coincident to HIPPO measurements. Also shown are the number of profiles and mean model biases below $9 \mathrm{~km}$ (with abundant measurements) at each band.

for $0-1 \mathrm{~km}$, layer 2 for $1-2 \mathrm{~km}$, etc.) during the five HIPPO campaigns. Compared to the global model, the two-way coupled simulation reduces the mean normalized bias relative to HIPPO CO in all but the 10th, 11th, and 12th layers (between $9 \mathrm{~km}$ and $12 \mathrm{~km}$ ). Note that comparisons at higher altitudes, especially above $10 \mathrm{~km}$, are subject to scarcity in measurements (Fig. 6a). In all layers, the two-way coupled model also slightly improves the correlation with HIPPO CO.

\subsection{Vertical profile of Pacific CO during HIPPO}

The thick yellow lines in Fig. 8a-e show the mean vertical distributions of $\mathrm{CO}$ measured from individual HIPPO campaigns. In general, the measured $\mathrm{CO}$ mixing ratios are larger in the lower and mid-troposphere than in the upper troposphere. The largest vertical contrast occurs during HIPPO3 in March-April 2010, with CO reaching 105 ppb near the surface and at around 5-6 km in contrast to a value of $60 \mathrm{ppb}$ at $12 \mathrm{~km}$. The vertical contrast reflects the strong springtime Asian outflow in the lower and mid-troposphere (Liu 
et al., 2003; Liang et al., 2004). By comparison, the vertical contrast is only about 10 ppb during HIPPO-4 in JuneJuly 2011, due to strong convective activities in the northern hemispheric summer that mix CO more evenly. During HIPPO-5 in August-September 2011, CO mixing ratios change by $20 \mathrm{ppb}$ at around $9 \mathrm{~km}$ due to the stratospheric influences. A similar change is also shown in model simulations, albeit with a smaller magnitude due possibly to model overestimations in the stratosphere.

The red lines in Fig. 8a-e show that the two-way coupled simulation captures the vertical distribution of HIPPO $\mathrm{CO}$. The bias is the smallest during HIPPO-1 (winter) where the model reproduces various fine structures of HIPPO CO throughout the troposphere (Fig. 8a). The two-way coupled simulations compare fairly well with HIPPO-2 (late fall) and HIPPO-5 (summer; except for the positive biases above $9 \mathrm{~km}$ as influenced by the stratosphere). For HIPPO-3 (spring), the coupled model reproduces the mid-tropospheric peak in the HIPPO data, but with a much smaller magnitude. This is likely due to the use of monthly biomass burning emissions that do not capture the episodic emissions occurring during the HIPPO-3 times. As shown in Fig. 3b, biomass burning is very active in this spring period. Likely for similar reasons, the coupled model also does not well capture the observed peaks in the lower and mid-troposphere in HIPPO-4 (summer). Averaged across the five campaigns (Fig. 8f), the twoway coupled simulation is within $3 \mathrm{ppb}$ of HIPPO CO below $9 \mathrm{~km}$ with an overestimation of $1-5 \mathrm{ppb}$ above $9 \mathrm{~km}$.

The black lines in Fig. 8a-e show that the global model also captures the general vertical structure of HIPPO CO, but with negative biases during all campaigns. Averaged across the five campaigns (Fig. 8f), the global model underestimates the HIPPO CO by $1-10 \mathrm{ppb}$ throughout the troposphere.

Figure 9 further evaluates the model simulations at six latitude bands of $30^{\circ}$ width (e.g., $60-90^{\circ} \mathrm{N}, 30-60^{\circ} \mathrm{N}$ ). Consistent with the above analyses, the two-way coupled model captures the vertical profiles of HIPPO CO measurements much better than the global model in the Northern Hemisphere (Fig. 9a, c, e). At $60-90^{\circ} \mathrm{N}$, both models do not capture the peak around $5 \mathrm{~km}$, while the two-way coupled model still has a smaller mean bias below $9 \mathrm{~km}$. Overall, the mean biases below $9 \mathrm{~km}$ are within $3 \mathrm{ppb}(3 \%)$ for the two-way coupled model at the three northern hemispheric bands, compared to the negative biases exceeding $11 \mathrm{ppb}(>10 \%)$ for the global model. At the three southern hemispheric bands (Fig. 9b, d, f), although the global model is slightly closer to HIPPO CO than the two-way coupled model at $30-60^{\circ} \mathrm{S}$, both models have small mean biases below $9 \mathrm{~km}$ (within $3 \mathrm{ppb})$ at all these bands.

\subsection{Implications of model resolution dependence for $\mathrm{CO}$ emission constraint}

Global models are often used to constrain CO emissions, where the mean model bias relative to measurements is at- tributed to emission errors (e.g., Stavrakou and Müller, 2006; Kopacz et al., 2010; Hooghiemstra et al., 2011). These studies tend to suggest $\mathrm{CO}$ emissions, as constrained by modeling and measurements, to be higher than those in emission inventories. For example, Kopacz et al. (2010) used satellite CO measurements and a $5^{\circ}$ long. $\times 4^{\circ}$ lat. global GEOS-Chem model to constrain CO emissions for 2004-2005. Their results suggested a total of global CO emissions from combustion (fossil fuel, biofuel and biomass burning combined) at $1350 \mathrm{Tg} \mathrm{yr}^{-1}$, much larger than current bottom-up emission inventories $\left(48 \%\right.$ larger than our value at $913 \mathrm{Tg} \mathrm{yr}^{-1}$ shown in Table 2). Previous studies have discussed uncertainties in model meteorology (Lin et al., 2012), transport (Liu et al., 2010; Jiang et al., 2013), chemistry (Lin et al., 2012) and the $\mathrm{OH}$ field (Kopacz et al., 2010; Hooghiemstra et al., 2011) affecting emission constraints. Here we show that the tropospheric $\mathrm{CO}$ simulated by the two-way coupled model is much higher than that simulated by the global model and is much closer to HIPPO measurements, as a consequence of improved representation of resolution-dependent emissions, chemistry, physics, and transport. This resolution effect is also consistent with our previous global model simulations, which show that a $5^{\circ}$ long. $\times 4^{\circ}$ lat. model leads to a $3 \%$ reduction in global tropospheric mean CO compared to a model at $2.5^{\circ}$ long. $\times 2^{\circ}$ lat. These results have important implications for using the global model to constrain $\mathrm{CO}$ emissions.

To elaborate on this point, we adjust $\mathrm{CO}$ emissions in the global model in an attempt to reproduce the two-way coupled simulation. We find that the global model simulation can resemble the two-way coupled simulation during HIPPO1 , especially below $4 \mathrm{~km}$, by increasing global $\mathrm{CO}$ emissions from all sources by $15 \%$ (Fig. 8a, green line). Emission increases with respect to other campaigns are $25 \%$ for HIPPO-2, $15 \%$ for HIPPO-3, $25 \%$ for HIPPO-4, and $35 \%$ for HIPPO-5 (Fig. 8b-e; green lines). Here all simulations start from July 2008 with adjusted CO emissions. The extent of required emission increases is larger than the magnitude of CO difference (about $11 \%$ based on Sects. 4.2 and 4.3), because emissions contribute less than half of tropospheric CO sources. As shown in Table 2, emissions contributed about $38 \%$ of tropospheric CO in 2009 , with the residual $62 \%$ attributed to oxidation of methane and NMVOCs. The simulation results here imply that, when used for emission constraints, the two-way coupled simulation would suggest much lower $\mathrm{CO}$ emissions to match measurements than the coarse-resolution global model.

\section{Conclusions}

We develop a two-way coupler (PKUCPL) to integrate the global GEOS-Chem CTM (at $2.5^{\circ}$ long. $\times 2^{\circ}$ lat.) and its three high-resolution nested models $\left(0.667^{\circ}\right.$ long. $\times 0.5^{\circ}$ lat. $)$ covering Asia, North America, and Europe. Under the cou- 
pling framework, the global model provides LBCs of chemicals for the nested models, while the nested models produce high-resolution results to improve the global model within the respective nested domains. The nested models encompass major anthropogenic pollutant source regions and better capture many small-scale nonlinear processes under-represented by the global model; moreover, the two-way coupling allows for such improvements to have a global impact.

Analysis for 2009 shows that the tropospheric CO concentrations simulated by the two-way coupled model are much higher than those simulated by the global model, with a difference of $10.4 \%$ averaged across the globe. The enhancement reaches $13.3 \%$ in the Northern Hemisphere, alleviating the northern hemispheric underestimation typical for global models (Naik et al., 2013). The increase in CO is accompanied by a $4.2 \%$ reduction in global mean tropospheric mean $\mathrm{OH}$, the magnitude of which is larger than the $\mathrm{OH}$ interannual variability estimated at $2.3 \%$ (Montzka et al., 2011). The reduction in $\mathrm{OH}$ content results in a $4.2 \%$ enhancement (from $5.3 \mathrm{yr}$ to $5.5 \mathrm{yr}$ ) in the MCF lifetime with respect to reaction with tropospheric $\mathrm{OH}$, bringing it closer to observationbased estimates at 6.0-6.3 yr (Prinn et al., 2005; Prather et al., 2012).

We delineate the factors differentiating the two-way coupled model from the global model in a simplified linear manner, taking for illustration the simulated $\mathrm{CO}$ concentration in January 2009. The two-way coupled simulation results in higher CO by $9.6 \%$ in January 2009. We find that a $4.6 \%$ enhancement is due to improved representation of smallscale spatial variability in $\mathrm{NO}_{\mathrm{x}}$, NMVOCs, and $\mathrm{CO}$ emissions (which greatly determine their concentration variability) resolved on the fine grid but not on the coarse grid. Another $3.5 \%$ enhancement is due to increased soil and lightning emissions of $\mathrm{NO}_{\mathrm{x}}$ and especially biogenic emissions of NMVOCs that are dependent of model meteorology and resolution. Furthermore, an additional $1.5 \%$ enhancement is due to improved simulation of vertical transport, radiation, and other resolution-dependent processes.

We use the two-way coupled model and the global model to simulate the tropospheric $\mathrm{CO}$ mixing ratios over the $\mathrm{Pa}$ cific during the five HIPPO campaigns in various seasons between 2009 and 2011. Both models capture the general seasonal, horizontal, and vertical distributions of HIPPO CO. Compared to the global model, the two-way coupled model correlates better with HIPPO CO spatiotemporally. Averaged across the five campaigns, $\mathrm{CO}$ simulated by the two-way coupled model is within $3 \mathrm{ppb}$ of HIPPO CO below $9 \mathrm{~km}$ with a positive bias of $1-5 \mathrm{ppb}$ above $9 \mathrm{~km}$; the mean bias is $1.1 \mathrm{ppb}(1.4 \%)$ between 0 and $9 \mathrm{~km}$. The global model underestimates HIPPO CO by $1-10 \mathrm{ppb}$ throughout the troposphere with a mean bias of $-7.2 \mathrm{ppb}(-9.2 \%)$ below $9 \mathrm{~km}$; the bias is most apparent over the North Pacific, consistent with the northern hemispheric underestimation typical for global models (Naik et al., 2013).
Our test simulations with the global model suggest that increasing the global $\mathrm{CO}$ emissions from all sources by about $15 \%$ would lead to $\mathrm{CO}$ mixing ratios comparable to those simulated by the two-way coupled model during HIPPO-1, especially below $4 \mathrm{~km}$; the respective emission increases are $25 \%$ for HIPPO-2, $15 \%$ for HIPPO-3, $25 \%$ for HIPPO-4, and $35 \%$ for HIPPO-5. These results imply an important model dependence on horizontal resolution that is largely unaccounted for in the literature on $\mathrm{CO}$ emission constraints.

Our two-way coupling framework minimizes the computational time and model complexity commonly concerned for multi-model integration. This is achieved by running all models in parallel under the regulation of the master coupler PKUCPL. With this coupler, it is straightforward to incorporate additional nested models with the same or different horizontal resolutions. In particular, a much finer nested GEOSChem model (at $0.3125^{\circ}$ long. $\times 0.25^{\circ}$ lat.) is currently available for North America and under development for other regions. As such, it is feasible to develop a low-computationalcost multi-regional multi-layer (e.g., from global $\sim 2^{\circ}$, regional $\sim 0.5^{\circ}$, and local $\sim 0.25^{\circ}$ ) two-way coupling system to facilitate research on the interactions between global, regional, and local scales. The coupled system will help address questions such as the impacts of megacities and urbanization on pollutant transport, global environment, and climate change (Parrish and Zhu, 2009).

Acknowledgements. This research is supported by the National Natural Science Foundation of China, grant 41175127, and the 973 program, grant 2014CB441303. We acknowledge the free use of HIPPO CO data from http://hippo.ornl.gov/dataaccess. HIPPO is funded by NSF and NOAA. We thank Yuanhong Zhao and Yan Xia for discussions.

Edited by: P. Jöckel

\section{References}

Akimoto, H.: Global air quality and pollution, Science, 302, 17161719, 2003.

Auvray, M. and Bey, I.: Long-range transport to Europe: seasonal variations and implications for the European ozone budget, J. Geophys. Res.-Atmos., 110, D11303, doi:10.1029/2004jd005503, 2005.

Chen, D., Wang, Y., McElroy, M. B., He, K., Yantosca, R. M., and Le Sager, P.: Regional CO pollution and export in China simulated by the high-resolution nested-grid GEOS-Chem model, Atmos. Chem. Phys., 9, 3825-3839, doi:10.5194/acp-9-3825-2009, 2009.

Cooper, O. R., Parrish, D. D., Stohl, A., Trainer, M., Nedelec, P., Thouret, V., Cammas, J. P., Oltmans, S. J., Johnson, B. J., Tarasick, D., Leblanc, T., McDermid, I. S., Jaffe, D., Gao, R., Stith, J., Ryerson, T., Aikin, K., Campos, T., Weinheimer, A., and Avery, M. A.: Increasing springtime ozone mixing ratios in the free 
troposphere over western North America, Nature, 463, 344-348, doi:10.1038/nature08708, 2010.

Fiore, A. M., Dentener, F. J., Wild, O., Cuvelier, C., Schultz, M. G., Hess, P., Textor, C., Schulz, M., Doherty, R. M., Horowitz, L. W., MacKenzie, I. A., Sanderson, M. G., Shindell, D. T., Stevenson, D. S., Szopa, S., Van Dingenen, R., Zeng, G., Atherton, C., Bergmann, D., Bey, I., Carmichael, G., Collins, W. J., Duncan, B. N., Faluvegi, G., Folberth, G., Gauss, M., Gong, S., Hauglustaine, D., Holloway, T., Isaksen, I. S. A., Jacob, D. J., Jonson, J. E., Kaminski, J. W., Keating, T. J., Lupu, A., Marmer, E., Montanaro, V., Park, R. J., Pitari, G., Pringle, K. J., Pyle, J. A., Schroeder, S., Vivanco, M. G., Wind, P., Wojcik, G., $\mathrm{Wu}$, S., and Zuber, A.: Multimodel estimates of intercontinental source-receptor relationships for ozone pollution, J. Geophys. Res.-Atmos., 114, D04301, doi:10.1029/2008jd010816, 2009.

Guan, D.-B., Lin, J.-T., Davis, S. J., Pan, D., He, K.-B., Wang, C., Wuebbles, D. J., Streets, D. G., and Zhang, Q.: Response to Lopez et al.: Consumption-based accounting helps mitigate global air pollution, P. Natl. Acad. Sci. USA, doi:10.1073/pnas.1407383111, 2014.

Guenther, A., Karl, T., Harley, P., Wiedinmyer, C., Palmer, P. I., and Geron, C.: Estimates of global terrestrial isoprene emissions using MEGAN (Model of Emissions of Gases and Aerosols from Nature), Atmos. Chem. Phys., 6, 3181-3210, doi:10.5194/acp-63181-2006, 2006.

Holtslag, A. A. M. and Boville, B. A.: Local versus nonlocal boundary-layer diffusion in a global climate model, J. Climate, 6, 1825-1842, doi:10.1175/15200442(1993)006<1825:lvnbld>2.0.co;2, 1993.

Hooghiemstra, P. B., Krol, M. C., Meirink, J. F., Bergamaschi, P., van der Werf, G. R., Novelli, P. C., Aben, I., and Röckmann, T.: Optimizing global $\mathrm{CO}$ emission estimates using a fourdimensional variational data assimilation system and surface network observations, Atmos. Chem. Phys., 11, 4705-4723, doi:10.5194/acp-11-4705-2011, 2011

HTAP: Hemispheric Transport of Air Pollution 2010 Executive SummaryECE/EB.AIR/2010/10 Corrected, United Nations, 2010.

Huang, H. C., Lin, J. T., Tao, Z. N., Choi, H., Patten, K., Kunkel, K., $\mathrm{Xu}$, M., Zhu, J. H., Liang, X. Z., Williams, A., Caughey, M., Wuebbles, D. J., and Wang, J. L.: Impacts of long-range transport of global pollutants and precursor gases on US air quality under future climatic conditions, J. Geophys. Res.-Atmos., 113, D19307, doi:10.1029/2007jd009469, 2008.

Janssens-Maenhout, G., Petrescu, A. M. R., Muntean, M., and Blujdea, V.: Verifying Greenhouse Gas Emissions: Methods to Support International Climate Agreements, The National Academies Press, 124 pp., 2010.

Jiang, Z., Jones, D., Worden, H. M., Deeter, M. N., Henze, D. K., Worden, J., Bowman, K. W., Brenninkmeijer, C., and Schuck, T.: Impact of model errors in convective transport on $\mathrm{CO}$ source estimates inferred from MOPITT CO retrievals, J. Geophys. Res.Atmos., 118, 2073-2083, 2013.

Jimenez, R., Herndon, S., Shorter, J. H., Nelson, D. D., McManus, J. B., and Zahniser, M. S.: Atmospheric trace gas measurements using a dual quantum-cascade laser mid-infrared absorption spectrometer, Proc.SPIE5738, Novel In-Plane Semiconductor Lasers IV, 318-331, doi:10.1117/12.597130, 2005.
Junhua Liu, Logan, J. A., Jones, D. B. A., Livesey, N. J., Megretskaia, I., Carouge, C., and Nedelec, P.: Analysis of CO in the tropical troposphere using Aura satellite data and the GEOSChem model: insights into transport characteristics of the GEOS meteorological products, Atmos. Chem. Phys., 10, $12207-$ 12232, doi:10.5194/acp-10-12207-2010, 2010.

Kopacz, M., Jacob, D. J., Fisher, J. A., Logan, J. A., Zhang, L., Megretskaia, I. A., Yantosca, R. M., Singh, K., Henze, D. K., Burrows, J. P., Buchwitz, M., Khlystova, I., McMillan, W. W., Gille, J. C., Edwards, D. P., Eldering, A., Thouret, V., and Nedelec, P.: Global estimates of CO sources with high resolution by adjoint inversion of multiple satellite datasets (MOPITT, AIRS, SCIAMACHY, TES), Atmos. Chem. Phys., 10, 855-876, doi:10.5194/acp-10-855-2010, 2010.

Kort, E. A., Wofsy, S. C., Daube, B. C., Diao, M., Elkins, J. W., Gao, R. S., Hintsa, E. J., Hurst, D. F., Jimenez, R., Moore, F. L., Spackman, J. R., and Zondlo, M. A.: Atmospheric observations of Arctic Ocean methane emissions up to 82 degrees north, Nat. Geosci., 5, 318-321, doi:10.1038/ngeo1452, 2012.

Krol, M., Houweling, S., Bregman, B., van den Broek, M., Segers, A., van Velthoven, P., Peters, W., Dentener, F., and Bergamaschi, P.: The two-way nested global chemistry-transport zoom model TM5: algorithm and applications, Atmos. Chem. Phys., 5, 417-432, doi:10.5194/acp-5-417-2005, 2005.

Kuhns, H., Etyemezian, V., Green, M., Hendrickson, K., McGown, M., Barton, K., and Pitchford, M.: Vehicle-based road dust emission measurement - Part II: Effect of precipitation, wintertime road sanding, and street sweepers on inferred $\mathrm{PM}_{10}$ emission potentials from paved and unpaved roads, Atmos. Environ., 37, 4573-4582, doi:10.1016/s1352-2310(03)00529-6, 2003.

Lam, Y. F. and Fu, J. S.: A novel downscaling technique for the linkage of global and regional air quality modeling, Atmos. Chem. Phys., 9, 9169-9185, doi:10.5194/acp-9-9169-2009, 2009.

Lamarque, J.-F., Shindell, D. T., Josse, B., Young, P. J., Cionni, I., Eyring, V., Bergmann, D., Cameron-Smith, P., Collins, W. J., Doherty, R., Dalsoren, S., Faluvegi, G., Folberth, G., Ghan, S. J., Horowitz, L. W., Lee, Y. H., MacKenzie, I. A., Nagashima, T., Naik, V., Plummer, D., Righi, M., Rumbold, S. T., Schulz, M., Skeie, R. B., Stevenson, D. S., Strode, S., Sudo, K., Szopa, S., Voulgarakis, A., and Zeng, G.: The Atmospheric Chemistry and Climate Model Intercomparison Project (ACCMIP): overview and description of models, simulations and climate diagnostics, Geosci. Model Dev., 6, 179-206, doi:10.5194/gmd-6-179-2013, 2013.

Liang, Q., Jaegle, L., Jaffe, D. A., Weiss-Penzias, P., Heckman, A., and Snow, J. A.: Long-range transport of Asian pollution to the northeast Pacific: seasonal variations and transport pathways of carbon monoxide, J. Geophys. Res.-Atmos., 109, D23s07, doi:10.1029/2003jd004402, 2004.

Lin, J.-T.: Satellite constraint for emissions of nitrogen oxides from anthropogenic, lightning and soil sources over East China on a high-resolution grid, Atmos. Chem. Phys., 12, 2881-2898, doi:10.5194/acp-12-2881-2012, 2012.

Lin, J.-T. and McElroy, M. B.: Impacts of boundary layer mixing on pollutant vertical profiles in the lower troposphere: implications to satellite remote sensing, Atmos. Environ., 44, 17261739, doi:10.1016/j.atmosenv.2010.02.009, 2010.

Lin, J.-T., Wuebbles, D. J., and Liang, X. Z.: Effects of intercontinental transport on surface ozone over the United States: present 
and future assessment with a global model, Geophys. Res. Lett., 35, L02805, doi:10.1029/2007g1031415, 2008a.

Lin, J.-T., Youn, D., Liang, X., and Wuebbles, D.: Global model simulation of summertime U.S. ozone diurnal cycle and its sensitivity to PBL mixing, spatial resolution, and emissions, Atmos. Environ., 42, 8470-8483, doi:10.1016/j.atmosenv.2008.08.012, 2008b.

Lin, J.-T., Liu, Z., Zhang, Q., Liu, H., Mao, J., and Zhuang, G.: Modeling uncertainties for tropospheric nitrogen dioxide columns affecting satellite-based inverse modeling of nitrogen oxides emissions, Atmos. Chem. Phys., 12, 12255-12275, doi:10.5194/acp-12-12255-2012, 2012.

Lin, J.-T., Pan, D., Davis, S. J., Zhang, Q., He, K., Wang, C., Streets, D. G., Wuebbles, D. J., and Guan, D.: China's international trade and air pollution in the United States, P. Natl. Acad. Sci. USA, 111, 1736-1741, doi:10.1073/pnas.1312860111, 2014.

Liu, H. Y., Jacob, D. J., Bey, I., Yantosca, R. M., Duncan, B. N., and Sachse, G. W.: Transport pathways for Asian pollution outflow over the Pacific: interannual and seasonal variations, J. Geophys. Res.-Atmos., 108, 8786-8800, doi:10.1029/2002jd003102, 2003.

Liu, J., Logan, J. A., Murray, L. T., Pumphrey, H. C., Schwartz, M. J., and Megretskaia, I. A.: Transport analysis and source attribution of seasonal and interannual variability of $\mathrm{CO}$ in the tropical upper troposphere and lower stratosphere, Atmos. Chem. Phys., 13, 129-146, doi:10.5194/acp-13-129-2013, 2013.

Montzka, S. A., Krol, M., Dlugokencky, E., Hall, B., Jockel, P., and Lelieveld, J.: Small interannual variability of global atmospheric hydroxyl, Science, 331, 67-69, doi:10.1126/science.1197640, 2011.

Murray, L. T., Logan, J. A., and Jacob, D. J.: Interannual variability in tropical tropospheric ozone and $\mathrm{OH}$ : the role of lightning, J. Geophys. Res.-Atmos., 118, 11468-11480, 2013.

Naik, V., Voulgarakis, A., Fiore, A. M., Horowitz, L. W., Lamarque, J.-F., Lin, M., Prather, M. J., Young, P. J., Bergmann, D., Cameron-Smith, P. J., Cionni, I., Collins, W. J., Dalsøren, S. B., Doherty, R., Eyring, V., Faluvegi, G., Folberth, G. A., Josse, B., Lee, Y. H., MacKenzie, I. A., Nagashima, T., van Noije, T. P. C., Plummer, D. A., Righi, M., Rumbold, S. T., Skeie, R., Shindell, D. T., Stevenson, D. S., Strode, S., Sudo, K., Szopa, S., and Zeng, G.: Preindustrial to present-day changes in tropospheric hydroxyl radical and methane lifetime from the Atmospheric Chemistry and Climate Model Intercomparison Project (ACCMIP), Atmos. Chem. Phys., 13, 5277-5298, doi:10.5194/acp13-5277-2013, 2013.

Olivier, J. G., Van Aardenne, J. A., Dentener, F. J., Pagliari, V., Ganzeveld, L. N., and Peters, J. A.: Recent trends in global greenhouse gas emissions: regional trends 1970-2000 and spatial distributionof key sources in 2000, Environm. Sci., 2, 81-99, 2005.

Ott, L. E., Pickering, K. E., Stenchikov, G. L., Allen, D. J., DeCaria, A. J., Ridley, B., Lin, R.-F., Lang, S., and Tao, W.$\mathrm{K}$.: Production of lightning $\mathrm{NO}(\mathrm{x})$ and its vertical distribution calculated from three-dimensional cloud-scale chemical transport model simulations, J. Geophys. Res.-Atmos., 115, D04301, doi:10.1029/2009jd011880, 2010.

Parrish, D. D. and Zhu, T.: Clean air for megacities, Science, 326, 674-675, 2009.
Pfister, G. G., Parrish, D. D., Worden, H., Emmons, L. K., Edwards, D. P., Wiedinmyer, C., Diskin, G. S., Huey, G., Oltmans, S. J., Thouret, V., Weinheimer, A., and Wisthaler, A.: Characterizing summertime chemical boundary conditions for airmasses entering the US West Coast, Atmos. Chem. Phys., 11, 1769-1790, doi:10.5194/acp-11-1769-2011, 2011.

Prather, M. J., Holmes, C. D., and Hsu, J.: Reactive greenhouse gas scenarios: systematic exploration of uncertainties and the role of atmospheric chemistry, Geophys. Res. Lett., 39, L09803, doi:10.1029/2012GL051440, 2012.

Price, C., Penner, J., and Prather, $\mathrm{M}$. : $\mathrm{NO}_{\mathrm{x}}$ from lightning. 1. Global distribution based on lightning physics, J. Geophys. Res.-Atmos., 102, 5929-5941, doi:10.1029/96jd03504, 1997.

Prinn, R., Huang, J., Weiss, R., Cunnold, D., Fraser, P., Simmonds, P., McCulloch, A., Harth, C., Reimann, S., and Salameh, P.: Evidence for variability of atmospheric hydroxyl radicals over the past quarter century, Geophys. Res. Lett., 32, L07809, doi:10.1029/2004GL022228, 2005.

Rienecker, E., Ryan, J., Blum, M., Dietz, C., Coletti, L., Marin III, R., and Bissett, W. P.: Mapping phytoplankton in situ using a laser-scattering sensor, Limnol. Oceanogr.-Meth., 6, 153-161, 2008.

Sauvage, B., Martin, R. V., van Donkelaar, A., Liu, X., Chance, K., Jaeglé, L., Palmer, P. I., Wu, S., and Fu, T.-M.: Remote sensed and in situ constraints on processes affecting tropical tropospheric ozone, Atmos. Chem. Phys., 7, 815-838, doi:10.5194/acp-7-815-2007, 2007.

Stavrakou, T. and Müller, J. F.: Grid-based versus big region approach for inverting $\mathrm{CO}$ emissions using Measurement of Pollution in the Troposphere (MOPITT) data, J. Geophys. Res.Atmos. (1984-2012), 111, D15304, doi:10.1029/2005JD006896, 2006.

Streets, D. G.: An inventory of gaseous and primary aerosol emissions in Asia in the year 2000, J. Geophys. Res., 108, 8809, doi:10.1029/2002jd003093, 2003.

van der Werf, G. R., Randerson, J. T., Giglio, L., Collatz, G. J., Kasibhatla, P. S., and Arellano Jr., A. F.: Interannual variability in global biomass burning emissions from 1997 to 2004, Atmos. Chem. Phys., 6, 3423-3441, doi:10.5194/acp-6-3423-2006, 2006.

van der Werf, G. R., Randerson, J. T., Giglio, L., Collatz, G. J., Mu, M., Kasibhatla, P. S., Morton, D. C., DeFries, R. S., Jin, Y., and van Leeuwen, T. T.: Global fire emissions and the contribution of deforestation, savanna, forest, agricultural, and peat fires (1997-2009), Atmos. Chem. Phys., 10, 11707-11735, doi:10.5194/acp-10-11707-2010, 2010.

Vinken, G. C. M., Boersma, K. F., van Donkelaar, A., and Zhang, L.: Constraints on ship $\mathrm{NO}_{\mathrm{x}}$ emissions in Europe using GEOSChem and $\mathrm{OMI}$ satellite $\mathrm{NO}_{2}$ observations, Atmos. Chem. Phys., 14, 1353-1369, doi:10.5194/acp-14-1353-2014, 2014.

Wang, Y., Jacob, D. J., and Logan, J. A.: Global simulation of tropospheric $\mathrm{O}_{3}-\mathrm{NO}_{\mathrm{x}}$-hydrocarbon chemistry, 1. Model formulation, J. Geophys. Res., 103, 10713-10725, doi:10.1029/98JD00158, 1998.

Wild, O. and Akimoto, H.: Intercontinental transport of ozone and its precursors in a three-dimensional global CTM, J. Geophys. Res.-Atmos., 106, 27729-27744, doi:10.1029/2000jd000123, 2001. 
Wofsy, S. C.: HIAPER Pole-to-Pole Observations (HIPPO): finegrained, global-scale measurements of climatically important atmospheric gases and aerosols, Philos. T. R. Soc. A, 369, 20732086, doi:10.1098/rsta.2010.0313, 2011.

Wuebbles, D. J., Lei, H., and Lin, J. T.: Intercontinental transport of aerosols and photochemical oxidants from Asia and its consequences, Environ. Pollut., 150, 65-84, doi:10.1016/j.envpol.2007.06.066, 2007.

Yienger, J. J. and Levy, H.: Empirical-model of global soil-biogenic $\mathrm{NO}_{\mathrm{x}}$ emissions, J. Geophys. Res.-Atmos., 100, 11447-11464, doi:10.1029/95jd00370, 1995.

Yu, H., Remer, L. A., Chin, M., Bian, H., Tan, Q., Yuan, T., and Zhang, Y.: Aerosols from overseas rival domestic emissions over North America, Science, 337, 566-569, doi:10.1126/science.1217576, 2012

Zhang, L., Jacob, D. J., Boersma, K. F., Jaffe, D. A., Olson, J. R., Bowman, K. W., Worden, J. R., Thompson, A. M., Avery, M. A., Cohen, R. C., Dibb, J. E., Flock, F. M., Fuelberg, H. E., Huey, L. G., McMillan, W. W., Singh, H. B., and Weinheimer, A. J.: Transpacific transport of ozone pollution and the effect of recent Asian emission increases on air quality in North America: an integrated analysis using satellite, aircraft, ozonesonde, and surface observations, Atmos. Chem. Phys., 8, 6117-6136, doi:10.5194/acp-8-6117-2008, 2008.
Zhang, L., Jacob, D. J., Downey, N. V., Wood, D. A., Blewitt, D., Carouge, C. C., van Donkelaar, A., Jones, D. B. A., Murray, L. T., and Wang, Y.: Improved estimate of the policyrelevant background ozone in the United States using the GEOS-Chem global model with $1 / 2^{\circ} \times 2 / 3^{\circ}$ horizontal resolution over North America, Atmos. Environ., 45, 6769-6776, doi:10.1016/j.atmosenv.2011.07.054, 2011.

Zhang, Q., Streets, D. G., Carmichael, G. R., He, K. B., Huo, H., Kannari, A., Klimont, Z., Park, I. S., Reddy, S., Fu, J. S., Chen, D., Duan, L., Lei, Y., Wang, L. T., and Yao, Z. L.: Asian emissions in 2006 for the NASA INTEX-B mission, Atmos. Chem. Phys., 9, 5131-5153, doi:10.5194/acp-9-5131-2009, 2009. 